\title{
AUDIT QUALITY: TREND REVIEW AND RESEARCH GAP BY USING CONTENT MINING TECHNIQUE
}

\author{
Fifitri Ali \\ Politeknik Caltex Riau \\ Email: fifitri@pcr.ac.id
}

\section{ARTICLE INFORMATION}

Article History

Received: 15 Mei 2019

Reviewed: 1 Juni 2019

Accepted: 15 Juni 2019

JEL Classification

M4, M42

Keywords:

Audit Quality,

Content Mining,

Bibliographic Coupling

\begin{abstract}
This study conducted a content mining technique to analyze the articles based on bibliographic coupling $(B C)$ to determine the salient research subjects. These audit quality research subjects were verified with those proxies by the International Auditing and Assurance Standard Boards (IAASB) framework with a total 520 articles from 1993 to 2018 were analyzed. The result found 14 topics based on bibliographic coupling analyze. In terms of most contributing countries, USA become the most influential countries in audit quality research. Moreover, this study also identified the highly cited references and most productive authors during 1993 to 2018. The results showed that auditor characteristic (AC) was the most attractive topics in audit quality research during 25 years. The results of this study will help researchers look into their own field specialties, understand the developing trends in audit quality research, indicate researchers who have had influence in audit quality research, and determine future research subjects.
\end{abstract}

\section{INTRODUCTION}

Content mining technique is an important aspect of data mining whose objective is to obtain knowledge from textual data that does not have structure or are partly structured (Choudary, Oluikpe, Harding, \& Carrillo, 2009). Thus by using content mining technique can assist in finding out patterns that are hidden than simple bibliometric analysis.

Most studies define audit quality as some variation of the "market-assessed joint probability that a given auditor will both detect a breach in the client's accounting system, and report the breach" (Deangelo, 1981). However, the study depicts auditing as a binary process and relegates the function of the auditor to mere uncovering and informing on "black and white" Generally Accepted Accounting Principles (GAAP) violations. Hence, it becomes more important that a methodical view of audit quality research is created. In the past, bibliometric analysis of audit quality research with the use of content mining technique was rarely investigated. Yet, there has not been enough studies which makes use of quantitative methods to look examine the development and prospect of audit quality research by analyzing citations and keywords (Sulaiman, Abdullah, \& Ismail, 2013).

The purpose of this study is to contribute to the audit literature through The International Auditing and Assurance Standard Board (IAASB) framework. This framework contains an all-inclusive description of the various component that makes up an input, output and contextual factor elements. This highlights the importance of audit quality, and it can be argued that a common aim of all audit research is to understand, evaluate or enhance audit quality. However, for the IAASB, which prepares standards for the auditing profession worldwide, it is beneficial to utilize evidence from research that has been undertaken within 
or across different countries in their standardsetting or regulatory processes.

\section{LITERATURE REVIEW Audit Quality}

Audit quality is defined in different ways. For example, Deangelo (1981) indicates that audit quality is a function of the auditor's ability to detect material misstatements and report the errors. Wallace (1980) defines audit quality as the degree that the auditors decrease the noise in the financial statement. In Financial Reporting Council (2008) Audit Quality Framework, the key drivers of audit quality includes the firm, audit partners and staff, the effectiveness of the audit process, the reliability and usefulness of audit reporting, and the factors outside the control of auditors.

\section{The International Auditing and Assurance Standards Board (IAASB) Framework for Audit}

The International Auditing and Assurance Standards Board (IAASB) is an independent standard-setting body that serves the public interest by setting high-quality international standards for auditing, quality control, review, other assurance, and related services, and by facilitating the convergence of international and national standards (IFAC, 2017). This framework describes in a holistic manner the different elements that create an environment for audit quality at the engagement, firm, and national levels, as well as relevant interactions contextual factors. This highlights the importance of audit quality, and it can be argued that a common aim of all audit research is to understand, evaluate or enhance audit quality.

The elements of the framework, and proxies divided into three elements. The first two elements are the Input and Outputs elements. The input element to audit quality includes auditor characteristic, auditor client contracting features, auditor judgement, audit procedures, audit review and audit tenure. The output element involves material misstatement, auditor communication, financial reporting quality, perception-based, disclosures and audit report. The third element relates to the contextual factors. The ten contextual factors identified in the framework are: (1) business practices and commercial law; (2) laws and regulations relating to financial reporting; (3) applicable financial reporting framework; (4) information systems; (5) corporate governance; (6) broader cultural factors; (7) audit regulation; (8) litigation environment; (9) attracting talents; and (10) financial reporting timetable. This framework allows for a synthesis of what has been learned regarding audit quality in the international context and allows for an identification of potential research gaps which will aid researchers' consideration of where and how the research can build on current knowledge and best add value.

\section{Analytical Tool}

The analytic process explained in this literature adheres to a typical workflow, as well as a number of information practices and follows from Chang, et al., (2010) research. All steps for explanatory prepare are adjusted into a software tool called Content Analysis Toolkit for Academic Research (CATAR). Asides clustering and grouping journals for identifying the sub-field which is the major reason for carrying out the analysis in the work, CATAR is also used for conducting general documents in order to analyze the topics from a set of freetext document

\section{METHOD}

By choosing the period of research from 1993 to 2018 , this analysis fills the research gap since the studies published by Simnett, et al., (2016), Porte, et al., (2016) and Valerica (2015). The first studies deal with the period from 1995 to 2014 , while the latter were carried out for the period from 2002 to 2014 . Therefore, this study extended research from all three previous studies that focus on less than 20 years of research. As the co-citation structures can vary considerably from year to year 
apparently randomly in trends of several years (Simnett, Carson, \& Vanstraelen, 2016) and because the Web of Science (WOS) database started in 1990, this study is decided to take period from 1993 to 2018.

As usual in content technique, only fulllength articles were analyzed, because this type of document provides complete bibliographic records to support bibliographic coupling analysis. As such, book reviews, conference reports, editor's comment and research notes were excluded.

\section{RESULT AND DISCUSSION}

\section{Characteristic of Bibliographic Coupling} Subject Areas

By using the content mining technique analysis, fourteen categories of audit quality emerged from the "audit quality" keyword during years 1993 to 2018. The cluster descriptors included in each topic categories are listed in Table 1. Based on the CATAR result, the fourteen topics were then manually adjusted by the audit quality proxy based on IAASB framework for ease of discussion. These tags and their sub-topical descriptors, as shown in Table 2, were: (1) auditor characteristics (AC); (2) auditor client contracting features (ACCF); (3) cultural factors/business practices (CFBP); (4) auditor judgement (AJ); (5) financial reporting quality (FRQ); (6) corporate governance (CG); (7) legal environment (LE); (8) perception based (PB); (9) material misstatement (MM); (10) audit law and regulation (ALR); (11) auditor communication (ACM); (12) audit procedures (AP); (13) financial reporting framework (FRF); (14) audit report (AR). As described in the method section, these 14 clusters emerged automatically from several sub cluster.

Table 1. Categories Extracted

\begin{tabular}{|c|c|c|}
\hline Topics & Documents & Subtopics \\
\hline $\begin{array}{l}\text { Topic } 1 \\
\text { Auditor Characteristics (AC) }\end{array}$ & 341 & $\begin{array}{l}\text { - Firm, Specialization, Quality (230) } \\
\text { - Audit, Industry, Industry Specialization (116) }\end{array}$ \\
\hline $\begin{array}{l}\text { Topic } 2 \\
\text { Auditor-Client Contracting Features } \\
\text { (ACCF) }\end{array}$ & 28 & Public-Sector, Determinant, Fee, Audit (28) \\
\hline $\begin{array}{l}\text { Topic } 3 \\
\text { Cultural Factors/Business Practices (CFBP) }\end{array}$ & 23 & $\begin{array}{l}\text { - Ethical, Time (16) } \\
\text { - Commitment, Behavior (7) }\end{array}$ \\
\hline $\begin{array}{l}\text { Topic } 4 \\
\text { Auditor Judgement (AJ) }\end{array}$ & 20 & $\begin{array}{l}\text { - Fraud, Identification (13) } \\
\text { - Professional Skepticism, Judgement, } \\
\text { Information (7) }\end{array}$ \\
\hline $\begin{array}{l}\text { Topic } 5 \\
\text { Financial Reporting Quality (FRQ) }\end{array}$ & 15 & $\begin{array}{l}\text { Protecting Investors Through Audit Oversight } \\
\text { (PCAOB), Accrual Accounting, Compliance (15) }\end{array}$ \\
\hline $\begin{array}{l}\text { Topic } 6 \\
\text { Corporate Governance (CG) }\end{array}$ & 13 & $\begin{array}{l}\text { - Internal Control, Remediation, Weakness, } \\
\text { Control Deficiency (5) } \\
\text { - Internal, Internal Audit, Reliance, External (8) }\end{array}$ \\
\hline $\begin{array}{l}\text { Topic } 7 \\
\text { Litigation Environment (LE) }\end{array}$ & 11 & Litigation Risk, Conservatism, Legal (11) \\
\hline $\begin{array}{l}\text { Topic } 8 \\
\text { Perception-Based (PB) }\end{array}$ & 10 & Market, Information Strategy System (10) \\
\hline $\begin{array}{l}\text { Topic } 9 \\
\text { Material Misstatement (MM) }\end{array}$ & 10 & $\begin{array}{l}\text { - Analyst, Analyst Information Precision (5) } \\
\text { - Restatement, Account Restatement (5) }\end{array}$ \\
\hline
\end{tabular}


Fifitri Ali: Audit Quality: Trend Review And Research ...

\begin{tabular}{|c|c|c|}
\hline Topics & Documents & Subtopics \\
\hline $\begin{array}{l}\text { Topic } 10 \\
\text { Audit Law and Regulations (ALR) }\end{array}$ & 6 & $\begin{array}{l}\text { Law, Standard (4) } \\
\text { Reform, Standard Setter and Audit Service } \\
\text { Supplier (2) }\end{array}$ \\
\hline $\begin{array}{l}\text { Topic } 11 \\
\text { Auditor Communication (ACM) }\end{array}$ & 5 & $\begin{array}{l}\text { Going-Concern, Opinion, Propensity, Going } \\
\text { Concern Opinion (5) }\end{array}$ \\
\hline $\begin{array}{l}\text { Topic } 12 \\
\text { Audit Procedures (AP) }\end{array}$ & 5 & Estimate, Account, Evidence, Audit (5) \\
\hline $\begin{array}{l}\text { Topic } 13 \\
\text { Financial Reporting Framework (FRF) }\end{array}$ & 5 & Financial Performance, Solvency (5) \\
\hline $\begin{array}{l}\text { Topic } 14 \\
\text { Audit Report (AR) }\end{array}$ & 4 & Decade, Rais, Stand, Researcher (4) \\
\hline Total Documents & & 496 \\
\hline
\end{tabular}

The fourteen topics cover 496 articles of the original 520 (due to the outlier removal during the MSC). As described by Chang, et al., (2010), outliers are articles 'dealing with independent and probably less-noticed issues. It could also be there are small clusters represent articles with citation pattern that do not match citation conventions in audit quality research and therefore do not map onto the salient topic domains. Therefore, there would be different total of articles based on journal distribution, yearly distribution, and major contribute countries.

In terms of labeling on the topic map, CATAR has its own code for easy naming of clusters as described in method section. As an example, 1840 in the AC topic refers to the cluster code of the CATAR system and 341 means the number of documents. Based on the MDS technique, the spatial relations among these topics are mapped in Fig. 1, where a circle denotes a topic and the size of the circle is designed to reflect the number of articles in it. As can be seen, the research topic of $A C$ emerged as the most popular topic in the field of audit quality research. There are 341 articles under this topic, amounting to $69 \%$ of the 496 networked researches from 1993 to 2018. According to topic map shown in Fig. 1, the research topics of AC, CG and ACCF have relatively closer relations. There are some issues within the three topics overstretched to each other. On the other hand, the audit quality research on topics among AJ and CFBP are closer to each other. Fig. 1 also shows that $F R Q, A C M$ and FRF are located in close proximity on the map, followed by LE, ALR and $A R$ which indicates similarity in their citation patterns. 


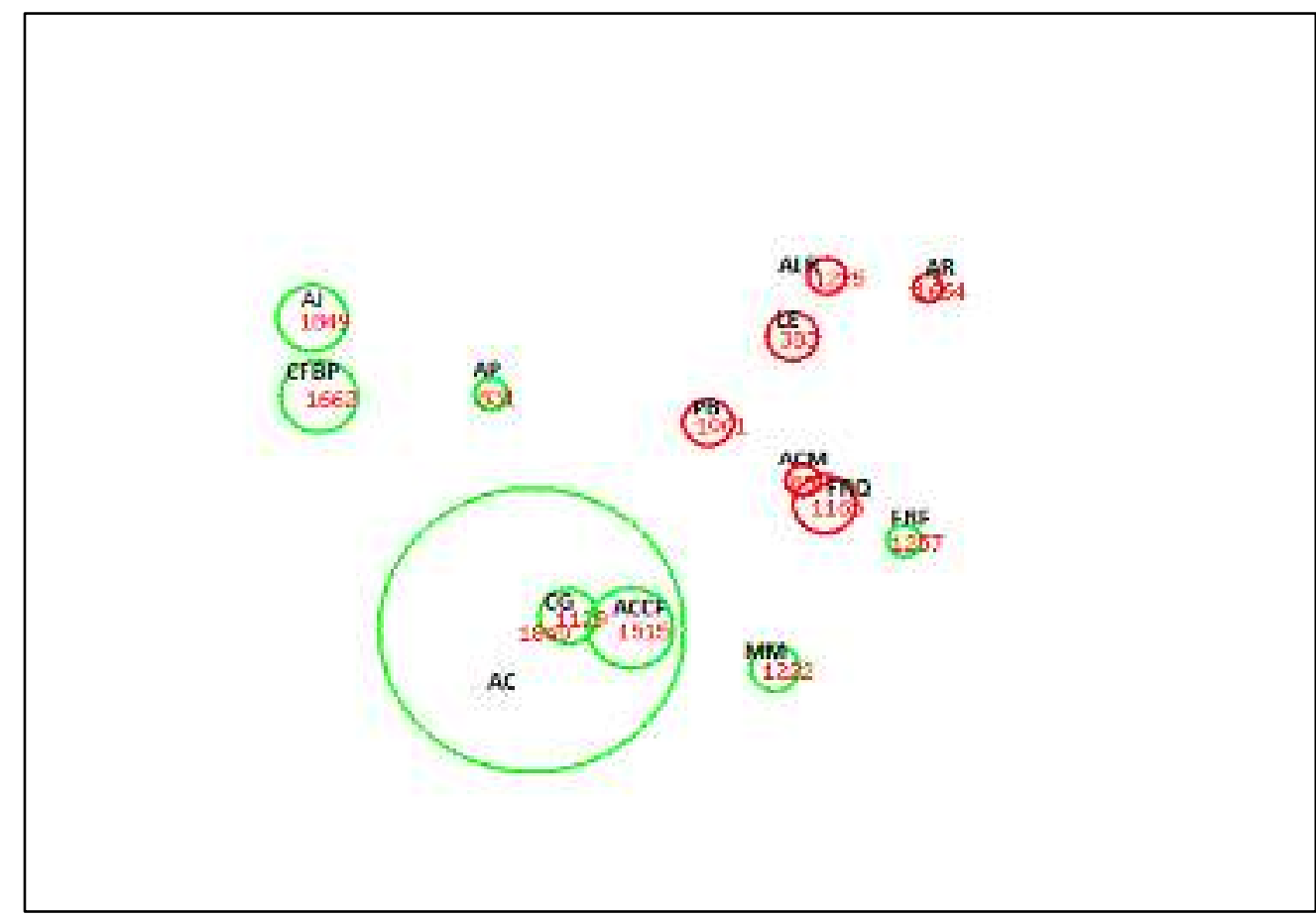

Fig. 1 Topic Map Rendered by Multi-Dimensional Scaling (MDS) From Multi-Stage Clustering of Audit Quality Keyword

\section{Topic Distribution for Each Topic}

Figure 2 lists the topic distribution of the journals and thus reveals the individual characteristics of the journals. The table suggests that some journal only published articles on certain topics, while others had a broader focus. Accounting Review and Auditing- A Journal of Practice \& Theory only two journals that almost attract publications across all the topics examined. Most paper published in Accounting Review and Auditing- $A$ Journal of Practice \& Theory are focused on auditor characteristics. Auditing- A Journal of Practice \& Theory also published numerous articles on AJ and FRQ. Mostly the topics in the output element have limited discussion in some journals. MM, ACM and PB topics only discussed in Accounting Horizons, Auditing-A Journal of Practice \& Theory and Accounting Review respectively. Finally, the findings suggest that some journals, such as African Journal of Business Management, Amfiteatru Economic, Review of Finance and Transformations in Business \& Economics are highly specialized, while others, such as Auditing- A Journal of Practice \& Theory, have broad coverage. 


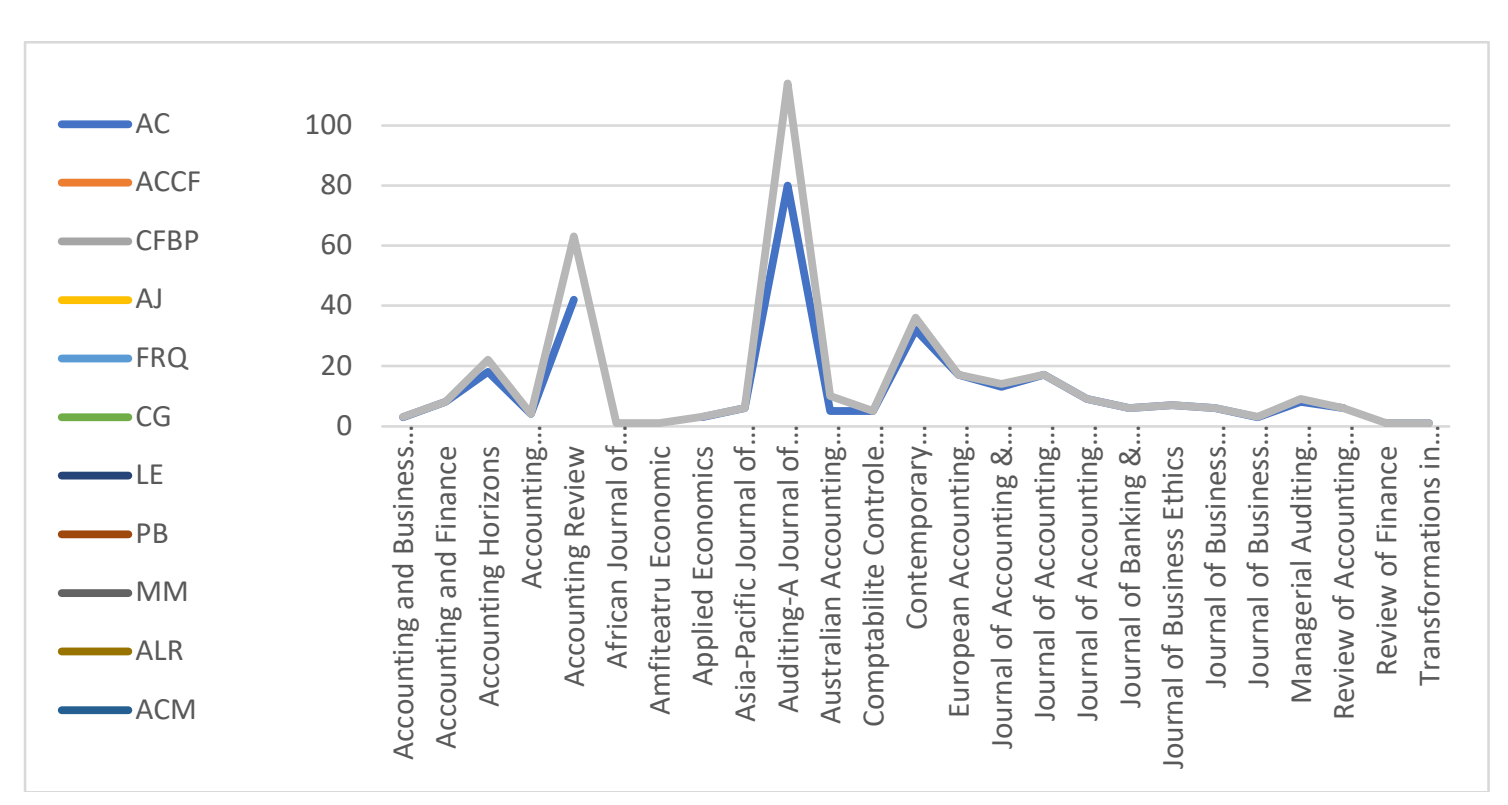

Figure 2. Number of Articles by Topic and by Journal

\section{Major Contributed Countries}

Figure 3 displays an illustration which indicates ten countries where the number of studies published between 1993 and 2018 are itemized. The slope is a line of "best fit" regarded to as the linear regression line which represents the number of studies published during a 25 years period. The linear regression line is also an indication of the productivity trend of each of the ten countries. The last row was a display of the ranks indicating the productivity trends of 39 countries where audit quality researches were published. From the rank listing, it is evident that more research papers were published in the USA than any other country and it also had the highest growth rate. On the other hand, South Korea has more publications than thirty other ranked countries and is the $5^{\text {th }}$ best country regarding growth rate.

Table 2 lists the top 10 contributing countries for each topic. A total of 39 countries contributed to audit quality research published during 1993 to 2018. The USA ranked the first in research production for eleven topics, namely $A C, A C C F, A J, C F B P, F R Q, L E, M M, C G$, $P B, A R$ and $A P$. Australia ranked the first for ALR topic followed by Romania as the first rank in FRF topic. Regarding the top 10 countries, English-speaking countries, including the USA and Australia, accounted for the bulk of audit research articles (68\%). Besides the Englishspeaking countries, non-English speaking countries such as Hongkong, China, Taiwan and South Korea also ranked in the 10 most productive countries. 
JIAFE (Jurnal Ilmiah Akuntansi Fakultas Ekonomi)

Vol. 5 No. 1, Juni 2019, Hal. 93-104

https://journal.unpak.ac.id/index.php/jiafe

P-ISSN: 2502-3020, E-ISSN: 2502-4159

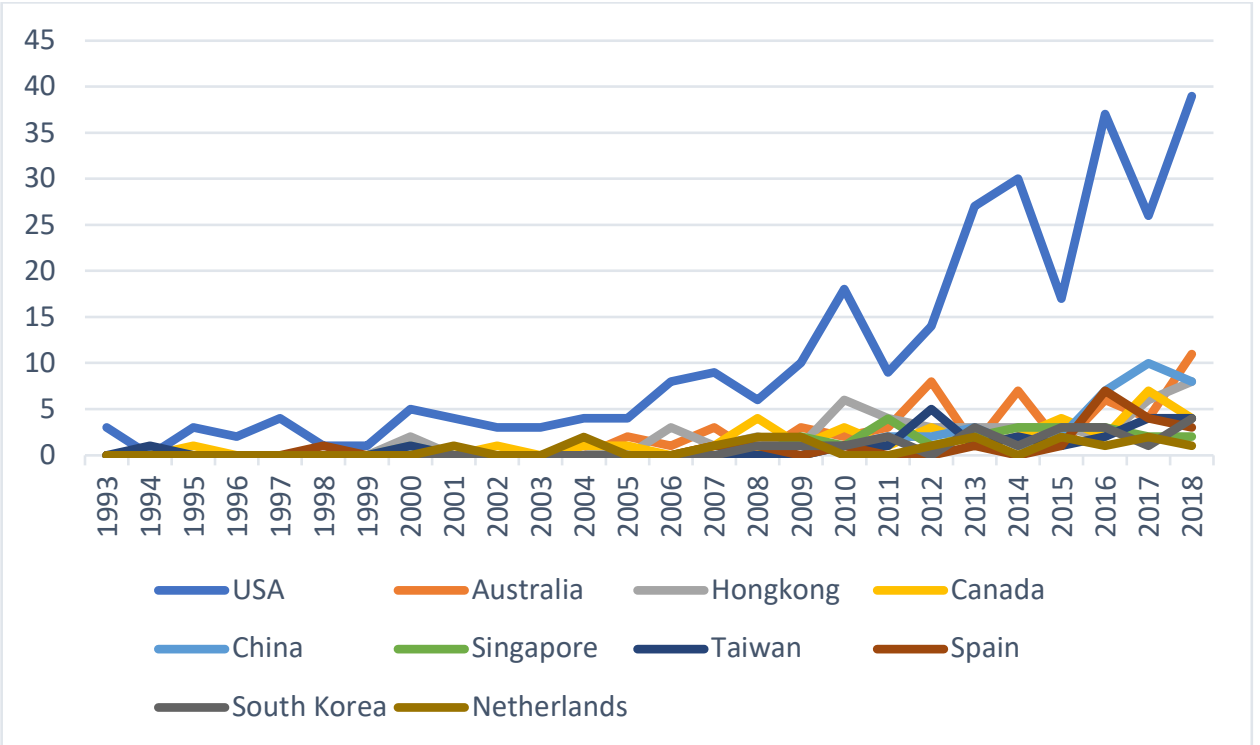

Fig. 3 Ten Most Productive Countries from 1993 to 2018

Table 2. Topics by Country

\begin{tabular}{|c|c|c|c|c|c|c|c|}
\hline AC & $\begin{array}{c}\text { Total } \\
\text { Articles }\end{array}$ & ACCF & $\begin{array}{c}\text { Total } \\
\text { Articles }\end{array}$ & AJ & $\begin{array}{c}\text { Total } \\
\text { Articles }\end{array}$ & CFBP & $\begin{array}{c}\text { Total } \\
\text { Articles }\end{array}$ \\
\hline USA & 182 & USA & 19 & USA & 18 & USA & 10 \\
\hline Hongkong & 42 & Spain & 4 & & & Australia & 4 \\
\hline Australia & 35 & & & & & Ireland & 3 \\
\hline China & 33 & & & & & Spain & 3 \\
\hline Canada & 25 & & & & & & \\
\hline Singapore & 22 & & & & & & \\
\hline South Korea & 19 & & & & & & \\
\hline Taiwan & 18 & & & & & & \\
\hline France & 14 & & & & & & \\
\hline UK & 13 & & & & & & \\
\hline FRQ & $\begin{array}{c}\text { Total } \\
\text { Articles }\end{array}$ & MM & $\begin{array}{c}\text { Total } \\
\text { Articles }\end{array}$ & LE & $\begin{array}{c}\text { Total } \\
\text { Articles }\end{array}$ & ALR & $\begin{array}{l}\text { Total } \\
\text { Articles }\end{array}$ \\
\hline USA & 8 & USA & 6 & $\begin{array}{l}\text { USA } \\
\text { Canada }\end{array}$ & $\begin{array}{l}6 \\
3\end{array}$ & Australia & 5 \\
\hline CG & $\begin{array}{c}\text { Total } \\
\text { Articles }\end{array}$ & PB & $\begin{array}{c}\text { Total } \\
\text { Articles }\end{array}$ & ACM & $\begin{array}{c}\text { Total } \\
\text { Articles }\end{array}$ & AR & $\begin{array}{c}\text { Total } \\
\text { Articles }\end{array}$ \\
\hline USA & 12 & USA & 7 & $\begin{array}{l}\text { China } \\
\text { Romania } \\
\text { Australia } \\
\text { USA } \\
\text { Hongkong }\end{array}$ & $\begin{array}{l}1 \\
1 \\
1 \\
1 \\
1\end{array}$ & USA & 2 \\
\hline AP & $\begin{array}{c}\text { Total } \\
\text { Articles }\end{array}$ & FRF & $\begin{array}{c}\text { Total } \\
\text { Articles }\end{array}$ & & & & \\
\hline USA & 5 & $\begin{array}{l}\text { Romania } \\
\text { USA } \\
\text { Canada }\end{array}$ & $\begin{array}{l}2 \\
2 \\
2\end{array}$ & & & & \\
\hline
\end{tabular}


Fifitri Ali: Audit Quality: Trend Review And Research ...

\section{Most Productive Authors}

Table 3 shows the most productive researchers in each of the fourteen topics in audit quality research. Several researchers have shown their research interest in more than one research topics with abundant publications. For example, Gul F.A, Kadous K, and Krishnan J, in addition to be ranked as the top ten most productive authors in various topics, have also shown one common research interest in the topic of Auditor Characteristic
(AC). To identify the active authors ranked highly in each of the research topics would help researchers recognize the works to be referenced and followed. However, it should be emphasized that, as this analysis employed the technique of bibliographic coupling in grouping the authors in the same topics, some very productive researches in audit quality missing in the table were either classified in several topics or were removed during the multi-stage clustering analysis.

Table 3. Most Productive Authors in The Fourteen Topics of Audit Quality Research from 1993 To 2018

\begin{tabular}{|c|c|c|c|c|}
\hline AC & Docs & ACCF & Docs & \\
\hline Knechel, WR & 11 & Krishnan, J & & 3 \\
\hline Choi, JH & 8 & & & \\
\hline Kim, JB & 8 & & & \\
\hline Francis, JR & 7 & & & \\
\hline Gul, FA & 7 & & & \\
\hline Khurana, IK & 7 & & & \\
\hline Raman, KK & 7 & & & \\
\hline Krishnan, J & 7 & & & \\
\hline Lennox, CS & 6 & & & \\
\hline Myers, LA & 5 & & & \\
\hline AJ & Docs & FRQ & Docs & \\
\hline Kadous, K & 5 & Jeter, DC & & 2 \\
\hline \multirow[t]{2}{*}{ Peecher, ME } & 4 & Okeefe, TB & & 2 \\
\hline & & Shaw, PE & & 2 \\
\hline LE & Docs & PB & Docs & \\
\hline Zhang, P & 2 & Brozovsky, JA & & 2 \\
\hline Radhakrishnan, S & 2 & Schwartz, R & & 2 \\
\hline Simunic, DA & 2 & & & \\
\hline ALR & Docs & ACM & Docs & \\
\hline Hecimovic, A & 2 & Brasoveanu, LV & & 1 \\
\hline Kend, $\mathrm{M}$ & 2 & Lennox, C & & 1 \\
\hline \multirow[t]{8}{*}{ Martinov-bennie, $\mathrm{N}$} & 2 & Liu, JH & & 1 \\
\hline & & Brad, L & & 1 \\
\hline & & Fargher, NL & & 1 \\
\hline & & Moon, JR & & 1 \\
\hline & & Wang, YP & & 1 \\
\hline & & Blay, AD & & 1 \\
\hline & & Wu, LS & & 1 \\
\hline & & Paterson, JS & & 1 \\
\hline FRF & Docs & AR & Docs & \\
\hline \multirow[t]{4}{*}{ Nedelcu, M } & 2 & Martin, $X$ & & 1 \\
\hline & & Monem, $\mathrm{R}$ & & 1 \\
\hline & & Lee, J & & 1 \\
\hline & & Palmrose, ZV & & 1 \\
\hline
\end{tabular}


JIAFE (Jurnal Ilmiah Akuntansi Fakultas Ekonomi)

Vol. 5 No. 1, Juni 2019, Hal. 93-104

https://journal.unpak.ac.id/index.php/jiafe

P-ISSN: 2502-3020, E-ISSN: 2502-4159

\begin{tabular}{|c|c|c|c|c|c|}
\hline$A C$ & Docs & & ACCF & Docs & \\
\hline & & & Frankel, $\mathrm{R}$ & & 1 \\
\hline & & & Shen, WC & & 1 \\
\hline & & & Donovan, J & & 1 \\
\hline & & & Seo, $\mathrm{H}$ & & 1 \\
\hline & & & Yeh, $\mathrm{CH}$ & & 1 \\
\hline \multirow[t]{2}{*}{$A R$} & Docs & & CFBP & Docs & \\
\hline & & & Barrainkua, I & 3 & \\
\hline Martin, $\mathrm{X}$ & & 1 & Woodliff, DR & 3 & \\
\hline Monem, R & & 1 & Espinosa-pike, M & 3 & \\
\hline Lee, J & & 1 & & & \\
\hline Palmrose, ZV & & 1 & & & \\
\hline Frankel, R & & 1 & & & \\
\hline Shen, WC & & 1 & & & \\
\hline Donovan, J & & 1 & & & \\
\hline Seo, $\mathrm{H}$ & & 1 & & & \\
\hline Yeh, $\mathrm{CH}$ & & 1 & & & \\
\hline CG & Docs & & AP & Docs & \\
\hline Abbott, LJ & & 3 & Hammersley, JS & 1 & \\
\hline Peters, GF & & 3 & Wolfe, CJ & 1 & \\
\hline \multirow[t]{2}{*}{ Parker, S } & & 3 & Bratten, B & 1 & \\
\hline & & & Newton, NJ & 1 & \\
\hline $\mathrm{MM}$ & Docs & & Kadous, K & 1 & \\
\hline Gul, FA & & 2 & Griffith, EE & 1 & \\
\hline \multirow[t]{4}{*}{ Lai, KMY } & & 2 & Hatfield, RC & 1 & \\
\hline & & & Commerford, BP & 1 & \\
\hline & & & Glover, SM & 1 & \\
\hline & & & Drake, MS & 1 & \\
\hline
\end{tabular}

Note: Docs= Total Documents

Yearly Distribution for Each Topic

Figure 4 shows the development trends for the fourteen topics. The topic of AC attracted most studies in the field of audit quality research. A sharp increase in the number of articles was observed in the period of 2012-2013. Although the research interests have become slightly declined in the 2015, it was still the most popular research topic in the field of audit quality research. 


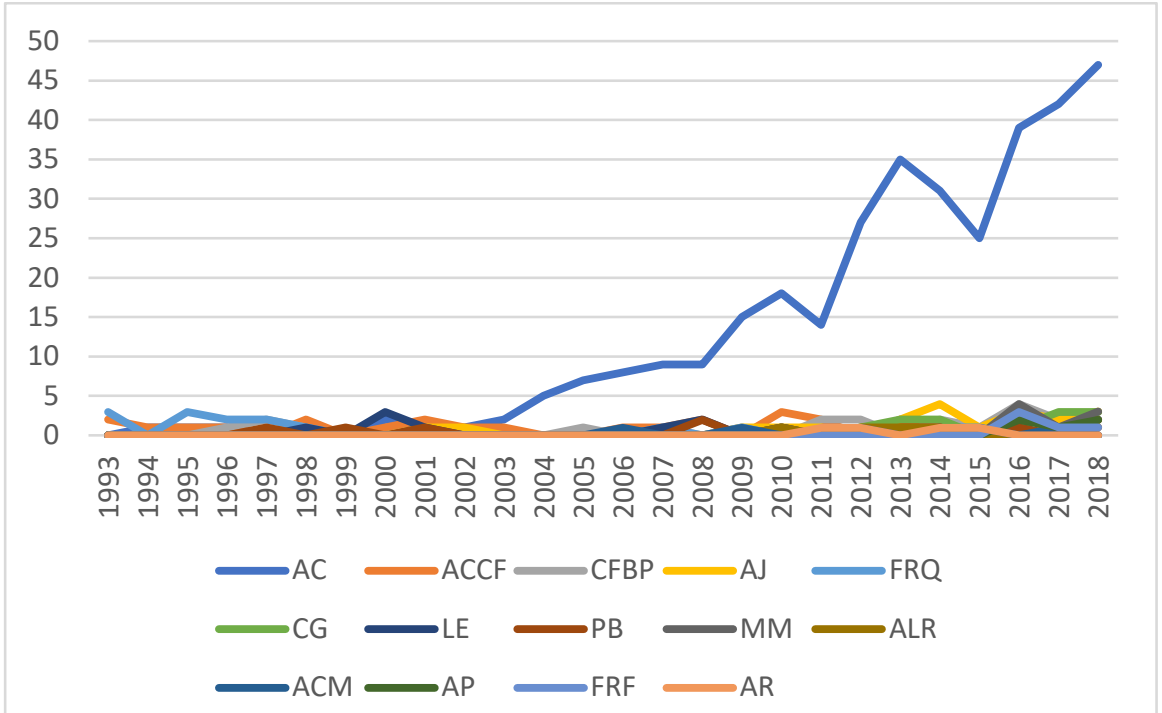

Fig 4. The Development Trends of Fourteen Topics in Audit Quality Research from 1993-2018

Table 4 shows the categories of corresponding topics that classified and have not been classified by CATAR. For topics that have not classified by CATAR, the possible causes are the literature collections collected by this study. There are no documents that relevant to these research topics, or research topics that are not desirable, for example Audit Industry and Structure, Attracting Talent, Financial Reporting Timetable and Information Systems.

Table 4. CATAR Unclassified Category Mapping Table in IAASB Theme Framework

\begin{tabular}{lll}
\hline & IAASB Topic Name & \multicolumn{1}{c}{ Subtopic } \\
\hline & Audit Industry and & \\
1 & Structure & Competition \\
2 & Attracting Talent & Staff Recruitment \\
& Financial Reporting & \\
3 & Timetable & Deadlines Report \\
& Information & High-Quality Financial \\
4 & Systems & Reporting \\
\hline
\end{tabular}

The findings on the development trend in this study echoed the evolution of research topic identified in previous reviews. Simnett, et al., (2016) observed trend in audit quality research and use the IAASB framework to grouping the sub-subject. The International Auditing and Assurance Standards Board
(IAASB) is an independent standard-setting body that serves the public interest by setting high-quality international standards for auditing is the more important core standard. Its subject classification framework is based on measurement of previous research.

This study found that automated tools were not able to analyze category topics that included in IAASB framework such as audit industry and structure, attracting talent, financial reporting timetable, information systems. Possibly because of the topics that are not well known, therefore it did not attract much attention from researchers. In line with this finding, Simnett, et al., (2016) identified financial reporting timetable and information systems were the topics that get lower number in term of discussion audit quality during 1999 to 2014.

As appeared within the investigation, the English-speaking countries/region counting the USA and Australia have contributed most the diary articles in review quality research. When tallying the foremost profitable nations, the analysts from non-English talking nations such as Hong Kong, China, Singapore and Taiwan were too noteworthy donors. It has been a creating drift that the field of review quality investigate in joining a broader run of social foundations (Kacanski \& Lusher, 2017). The 
expanding appearance of analysts from the non-English talking nations within the Englishlanguage diaries moreover appeared the acknowledgment of their commitment by the worldwide diaries. In expansion, moving forward analysts from the non-English talking nations to contribute their investigate discoveries and viewpoint to the worldwide community may improve the worldwide exchange and differing qualities.

\section{CONCLUSION}

The content mining technique conducted in this study were valuable and different from relevant studies presented previously. First, used proxies from the International Auditing and Assurance Standard Boards (IAASB) framework to determine the topics from different categories in audit quality research, while previously research work may not have used standards to determine it all (refer to the review by Defond \& Zhang (2014). The proxies from IAASB framework may more reflect the details to categorize the topics because this study interpreted the commonly used proxies that have been analyzed by researchers from previous study.

Second, research subjects in the field of audit quality are under continuous change as they are influenced by auditing standard. Regular subject analysis with the international auditing standard is therefore important to assist researchers in understanding the past, present, and future directions of research. Content mining technique can also improve the efficiency of manual analyses (Lee, Chen, \& Tseng, 2013).

As a follow-up to Defond \& Zhang (2014) research, this study analyzed the related audit quality articles in 1993-2018. The research trends about topics, methods, as well as the most highlighted issues revealed in this study, to some extent, illustrated the development of research in the field of audit quality in the past, and may also suggest some possible directions for the development of further research in this field. It is hoped that this study will be beneficial for researchers and educators in conducting their research in audit quality, and in publishing their research findings.

This study also aims at providing opportunities for researchers to do research in audit quality topics that do not attract much attention from researchers, such as audit industry and structure, attracting talent, financial reporting timetable and information systems. The other is that research notes, conference reports, monographs, dissertation, course syllabi book chapter or editor's comments also be included for comprehensive study, as journal articles are not the only sources of ideas or knowledge for analysis.

\section{REFERENCE}

Chang, Y. H., Chang, C. Y., \& Tseng, Y. H. (2010). Trends of Science Education Research: An Automatic Content Analysis. Journal of Science Education and Technology, 728-740.

Choudary, A. K., Oluikpe, P. I., Harding, J. A., \& Carrillo, P. M. (2009). The Needs and Benefits of Text Mining Applications on Post-Project Reviews. Computers in Industry, 728-740.

Deangelo, L. E. (1981). Auditor Independence, "Low Balling",and Disclosure Regulation. Journal of Accounting and Economics, 113-127.

Defond, M., \& Zhang, J. (2014). A Review of Archival Auditing Research. Journal of Accounting and Economics, 275-326.

IFAC. (2017). About IAASB. https://www.iaasb.org/about-iaasb (Accessed on January 18,2019).

Kacanski, S., \& Lusher, D. (2017). The Application of Social Network Analysis to Accounting and Auditing. International Journal of Academic Research in Accounting, Finance and Management Sciences, 182-197. 
Lee, C. F., Chen, C. M., \& Tseng, Y. H. (2013). Subject Analysis on the Field of the ELearning Research.

Porte, M., Amaral, I., \& Pinho, C. (2016). Research in Auditing: Main Themes. Revista Contabilidade \& Financas.

Pujari, A.K. (2001). Data Mining Techniques. Universities Press.

Simnett, R., Carson, E., \& Vanstraelen, A. (2016). International Archival Auditing and Assurance Research: Trends, Methodological Issues and Opportunities. Auditing: A Journal of Practice \& Theory, 1-32.

Sulaiman, N., Abdullah, M., \& Ismail, K. (2013). Audit Quality in Practice: A Critical Analysis of the Financial Reporting
Council (FRC) Discussion Paper. Journal of Modern Accounting and Auditing, 1564-1573.

Valerica, G. (2015). Analysis Method of Research Papers Published for Audit Domain, Based on Titles and Keywords. Economy Series.

Wallace, W. (1980). The Economic Role of the Audit in Free and Regulated Markets. The Touche Ross and Co. Aid to Education Program.

Yuan, Y., Gretzel, U., \& Tseng, Y.H. (2015). Revealing the Nature of Contemporary Tourism Research: Extracting Common Subject Areas through Bibliographic Coupling. International Journal of Tourism Research, 417-431. 